\title{
HUBUNGAN KONFORMITAS DENGAN PROKRASTINASI AKADEMIK PADA MAHASISWA DI KOTA MAKASSAR
}

Trisnawaty ${ }^{1}$, Noorrayda ${ }^{2}$

${ }^{1}$ Fakultas Kedokteran dan Ilmu Kesehatan UIN Alauddin, ${ }^{2}$ Konsultasi Pelangi Hati Makassar

\begin{abstract}
Abstrak
Jenis Prokrastinasi akademik merupakan penundaan yang dilakukan berulang-ulang secara sengaja dan menimbulkan perasaan tidak nyaman terhadap pelakunya. Sedangkan konformitas adalah perilaku atau tindakan seseorang yang dipengaruhi oleh kelompok yang telah disepakati agar sesuia dengan aturan atau norma kelompok atau sosial lingkungan kelompok tersebut.

Penelitian ini memiliki tujuan untuk mengetahui seberapa besar hubungan konformitas dengan prokrastinasi akademik pada mahasiswa di kota Makassar, jumlah responden sebanyak 184 orang. Data penelitian diperoleh dengan menggunakan kuesioner berdasarkan skala Likert. Kuesioner tersebut dianalisis berdasarkan metode deskriptif kuantitatif yang memenuhi persyaratan validitas dan realibilitas yang menggunakan corellation product moment person dengan bantuan komputerisasi.

Berdasarkan analisis yang telah dilakukan menunjukkan bahwa konformitas mempunyai hubungan yang kuat dan signifikan dengan prokrastinasi akademik pada mahasiswa. besarnya korelasi antara konformitas dengan prokrastinasi akademik adalah 0,224 dengan tingkat signifikansi koefisien korelasi adalah 0,002 atau p sebesar 0,002. Karena probabilitas jauh di bawah standar signifikan $5 \%$ atau 0,05 maka konformitas dengan prokrastinasi akademik memiliki hubungan yang kuat (signifikan) dengan prokrastinasi akademik pada mahasiswa di Kota Makassar
\end{abstract}

Kata kunci : Konformitas, Prokrastinasi Akademik, Mahasiswa

\section{Pendahuluan}

Prokrastinasi akademik merupakan penundaan yang dilakukan berulang-ulang secara sengaja dan menimbulkan perasaan tidak nyaman terhadap pelakunya. Sedangkan konformitas adalah perilaku atau tindakan seseorang yang dipengaruhi oleh kelompok yang telah disepakati agar sesuia dengan aturan atau norma kelompok atau sosial lingkungan kelompok tersebut. Kedua variabel ini amatlah dekat dengan kehidupan peserta didik atau mahasiswa.

Mahasiswa merupakan peserta didik yang sedang mejalani pendidikan pada perguruan tinggi. Hal ini tercantum pada
UU. No 30 tahun $1990^{1}$. Aktifitas yang paling penting dilakukan sebagai seorang pelajar khususnya mahasiswa adalah belajar, sebab mereka merupakan calon pemimpin di masa depan untuk memajukan Negara. Umumnya mahasiswa tersebut memiliki usia memasuki remaja akhir yang baru saja menyelesaikan pendidikannya di sekolah menengah akhir (SMA). Menurut Santrock $^{2}$ masa ini berkisar antara 18-27 tahun, masa ini merupakan akhir masa remaja seseorang dan merupakan awal dari dewasa awal. Pada masa ini merupakan masa kemandirian dalam membuat keputusan hidup dan menjadi awal untuk 
mempertanggung jawabkan perbuatannya. Sebagai seorang mahasiswa juga selain dituntut untuk belajar mereka juga dituntut untuk mengikuti organisasi baik di dalam kampus maupun organisasi di luar lainnya yang bermanfaat bagi dirinya sendiri maupun untuk orang lain. Mahasiswa tersebut memiliki harapan untuk mendapatkan berbagai ilmu pengetahuan yang bisa dicapainya selama berada di bangku perkuliahan, karena setiap orang yang masuk dibangku kuliah memiliki tujuannya masing-masing. Agar setelah selesai mereka memiliki pengalaman dan pengetahuan yang bisa membantu saat terlibat langsung di masyarakat. Setiap orang pasti memiliki harapan ingin sukses, untuk membahagiakan orang tua dan menjadi berguna bagi bangsa. Sehingga saat seorang memasuki bangku perguruan tinggi, mereka memiliki komitmen dan target penyelesaian pendidikan mereka dalam waktu tidak lebih dari 4 tahun. Tetapi, setelah menjalani perkuliahan tidak semua mahasiswa menggunakan waktunya dengan baik selama berada di perguruan tinggi, sebagian mahasiswa mulai menunda-nunda untuk mengerjakan tugastugas yang diberikan oleh dosen sehingga target penyelesaiannya pun tertunda. Penunda-nundaan itu biasa disebut prokrastinasi akademik. Adapun dalam beberapa penelitian, seperti Penelitian yang dilakukan oleh Solomon and Rothblum ${ }^{3}$, diketahui bahwa pada mahasiswa yang sedang melakukan tugas akhir, terdapat $50 \%$ sampai $90 \%$ terjadi prokrastinasi akademik. Penelitian yang sama dilakukan oleh Knaus $^{4}$ yang menemukan bahwa mahasiswa di AS, 95\% dengan sengaja menunda mengerjakan atau menyelesaikan tugas, dan pada penelitian tersebut juga menggambarkan bahwa mahasiswa yang tergolong sering melakukan prokrastinasi akademik sebesar $70 \%$.

Pada beberapa kondisi, masyarakat yang ada Indonesia juga masih suka menunda-nunda pekerjaan. Adapun beberapa penelitian yang dilakukan menunjukkan bahwa beberapa mahasiswa di universitas yang ada di Indonesia masih mengalami prokrastinasi yang cukup besar. Salah satu penelitian yang dilakukan oleh Sari $^{2}$ memperlihatkan bahwa prokrastinasi di perguruan tinggi yang ada di Sumatera Utara melakukan prokrastinasi. Penelitian tersebut menyebutkan angka 48,5\% dari 66 sample yang diteliti melakukan prokrastinasi. Senada dengan peneltian tersebut, penelitian yang dilakukan oleh Kartadinata dan Tjundjing ${ }^{4}$ pada sebuah perguruan tinggi di Surabaya menggambarkan bahwa mahasiswa melakukan prokrastinasi akademik. Penelitian ini memiliki subyek 60 mahasiswa dan 95\% dari subyek penelitian menyatakan sering melakukan prokrastinasi akademik. 
Menurut Ghufron dan Risnawita ${ }^{3}$, jika seseorang sering melakukan penundaan dan tidak memulai pekerjaann dengan sesegera mungkin, maka Ia termasuk yang melakukan prokrastinasi. Tidak peduli apakah penundaan tersebut dilakukan dengan sengaja atau tidak sengaja. Pada kondisi seorang mahasiswa, terdapat banyak faktor lain yang menjadi penyebab mahasiswa melakukan prokrastinasi, salah satunya ketika seseorang memiliki teman dan memiliki kekompakan dalam hal tertentu dengan orang lain, mereka cenderung mulai melakukan pembentukan kelompok atau mengikuti salah satu kelompok yang mengharuskan mereka untuk melakukan sesuatu agar mereka bisa masuk dalam kelompok tersebut. Saat mahasiswa selalu memprioritaskan dan mementingkan keinginan kelompok maka mereka akan kehilangan kebebasan untuk melakukan hal lainnya dan akan mempengaruhi bagi dirinya baik bidang akademik maupun yang lainnya. Ketika hal itu mempengaruhi dibidang akademik mereka maka mahasiswa tersebut akan mendapat nilai yang jelek, IPK yang rendah dan kuliah mereka pun mulai tertunda. Hal ini menunjukan keterkaitan antara mengikuti keinginan kelompok dengan konformitas. Menurut Cialdini dan Goldstein $^{6}$, konformitas merupakan suatu bentuk tendensi untuk melakukan pengubahan suatu keyakinan atau suatu perilaku seseorang agar sesuai dengan perilaku orang lain atau standar kelompok yang telah disepakati. Adapun menurut Santrock ${ }^{1}$, konformitas akan muncul pada individu yang meniru sikap ataupun tingkah laku orang lain disebabkan adanya tekanan dari kelompok yang ditiru.

\section{Bahan dan Metode}

Rancangan penelitian yang digunakan merupakan penelitian kuantitatif dengan maksud untuk mengetahui bagaimana hubungan antara konformitas dengan prokrastinasi akademik pada mahasiswa. Dengan variabel $\mathrm{X}$ adalah konformitas dan variabel $\mathrm{Y}$ adalah Prokrastinasi. Adapun populasi dari penelitian ini adalah 362 mahasiswa dari fakultas hukun dan psikologi dari berbagai perguruan tinggi di makassar dengan karaktersitik usia antara 19-21 tahun, masih berstatus mahsiswa yang mengikuti kelas reguler/aktif dan telah melewati beberapa semester, saat pengambilan data mahasiswa sedang berada di semester 6. Adapun sampel ditarik dari teknik sampling purposive sampling dengan menggunakan tabel Krejcie dan Morgan $^{8}$ yang jumlah samplenya 184 mahasiswa dari 362 populasi mahasiswa. Teknik pengumpulan data dalam penelitian ini menggunakan Questioner atau Skala yang mengacu pada skala liker. Dalam penelitian ini, terdapat dua questioner atau skala yaitu questioner 
atau skala untuk mengukur konformitas dan questioner atau skala untuk mengukur prokrastinasi akademik.

Skala Konformitas, skala ini memiliki 3 aspek, yaitu (1). Perilaku, dengan indikatornya: a. pendapat kelompok yang disepakati, b. Tekanan kelompok; (2). Penampilan. Dengan indikatornya: menangung resiko yang tidak mengikuti kelompok; (3). Pandangan. Dengan indikatornya: a. Pandangan individu lain tentang dirinya, b. Ciri khas individu dalam kelompok. Pada Skala Konformitas, terdapat 30 pernyataannya yang terdiri dari pernyataan mendukung (favorabel) dan yang tidak mendukung (unfavorable). Dalam tiap indikator akan di sediakan empat pilihan respon nantinya akan dipilih oleh responden yakni memiliki item (SS) Sangat Setuju, (S) Setuju, (TS) Tidak Setuju, (STS) Sangat Tidak Setuju.

Skala Prokrastinasi Akademik, memiliki 4 aspek yaitu: (1). Penundaan untuk memulai dan meyelesaikan tugas. Dengan indikatornya: a. Penundaan untuk memulai pengerjaan tugas, b. Penundaan untuk menyelesaikan pengerjaan tugas; (2). Keterlambatan dalam mengerjakan tugas, dengan indikatornya: memerlukan waktu yang lebih lama dalam mengerjakan tugas; (3). Kesengajaan waktu antara rencana dan kinerja aktual. Dengan indikatornya: a. Keterlambatan waktu dalam mengerjakan tugas yang ditentukan, b. Ketidak seusainan rencana dan waktu yang ingin di kerjakan; (4). Melakukan tugas yang lebih menyenangkan. Dengan indikatornya: melakukan kegiatan yang menyenangkan daripada tugas yang harus dikerjakan. Untuk Skala Prokrastinasi Akademik, terdapat 25 pernyataannya yang terdiri dari pernyataan mendukung (favorabel) dan yang tidak mendukung (unfavorable). Dalam tiap indikator akan di sediakan empat pilihan respon nantinya akan dipilih oleh responden yakni memiliki item (SS) Sangat Setuju, (S) Setuju, (TS) Tidak Setuju, (STS) Sangat Tidak Setuju.

Metode analisis data yang peneliti gunakan untuk melihat hubungan antara konformitas dengan prokrastinasi akademik menggunakan analisis statistik deskriptif. Menurut Azwar ${ }^{7}$, statistik deskriptif digunakan bila peneliti hanya ingin mendeskripsikan data sampel dan tidak ingin membuat kesimpulan yang berlaku untuk populasi di mana sampel diambil. Selain itu, keseluruhan komputasi data dalam penelitian ini dilakukan dengan menggunakan program komputer Statistical Package For Social Science (SPSS) for Windows versi $22.0^{10}$

\section{Uji Validitas dan Realibilitas}

$>$ Uji Validitas

Hasil uji coba skala konformitas dengan total item sebanyak 30 dan prokrastinasi akademik dengan total item 
sebanyak 30, maka ditemukan 6 item yang gugur pada skala komformitas yaitu 6, 20, 21, 23, 24 dan 29, serta ditemukan 5 item yang gugur pada skala prokrastinasi akademik yaitu 13, 14, 19, 23, dan 25, hasil ini dapat dilihat pada lampiran. Banyak item yang gugur kemungkinan dipengaruhi oleh kondisi responden, mengisi pernyataan ikut-ikutan, pernyataan yang tidak sesuai dengan kondisi responden, cara penyusunan item yang tidak teracak dan lain-lain

\section{Uji Realibilitas}

Uji realibilitas pada skala komformitas sebesar 0,914 dan koefisien skala prokrastinasi akademik sebesar 0,901. Reliabilitas skala komformitas dan prokrastinasi akademik masuk pada kategori tingkat reliabitas tinggi.

\section{Hasil Penelitian}

Penelitian melalui tahap uji normalitas dan linearitas. Data dinyatakan berdistribusi normal adalah data dengan nilai signifikansi $(\mathrm{p})>0,05$. Tabel diatas menunjukan kedua variabel dalam penelitian ini terdistribusi dengan normal. Hal ini dapat dilihat pada tabel 1.

Adapun Kriteria nilai signifikansi linearity $<0,05$ dan nilai signifikansi deviation from linearity $>0,05$. Hal tersebut menunjukan hubungan konformitas dengan prokrastinasi akademik mahasiswa adalah linier. Besarnya kontribusi konformitas terhadap prokrastinasi akademik adalah sebesar 9,6\% sedangkan sisanya 90,4\% di tentukan oleh variabel lain. Hal ini dapat dilihat pada tabel 2 (lampiran). Konformitas memiliki hubungan yang sangat kuat terhadap prokrastinasi akademik. Hal ini juga di tunjukan oleh coefficient signifikan 0,002 lebih kecil daripada nilai probabilitas 0,05. Hal ini juga dapat dilihat pada tabel 3 (Lampiran).

Berdasarkan hasil pengujian hipotesis diperoleh bahwa adanya hubungan antara konformitas dengan prokrastinasi akademik dengan menggunakan teknik korelasi product moment sebesar 0,224, dengan taraf signifikansi atau $\mathrm{p}$ sebesar 0,002. Aturan yang digunakan dalam penelitian ini: jika besaran signifikan di bawah 0,05 (p<0,05) maka $\mathrm{H}_{1}$ diterima dan $\mathrm{H}_{0}$ ditolak dan jika di atas $0,05(\mathrm{p}>0,05) \mathrm{H}_{0}$ diterima dan $\mathrm{H}_{1}$ ditolak $^{7}$. Konformitas memiliki hubungan yang sangat kuat dengan prokrastinasi akademik. Hal ini juga di tunjukan oleh coefficient signifikan 0,002 lebih kecil daripada nilai probabilitas 0,05 . Hal ini berarti jika konformitas meningkat maka akan diikuti dengan meningkatnya prokrastinasi akademik pada mahasiswa, sebaliknya jika konformitas tidak meningkat maka akan diikuti dengan tidak meningkatnya prokrastinasi akademik pada mahasiswa di kota Makassar.

Sehingga ditemukan bahwa besarnya tingkat signifikansi koefisien korelasi 
adalah 0,002 yang di ukur dari probabilitas. Karena probabilitas jauh di bawah standar signifikan $5 \%$ atau 0,05 maka konformitas dengan prokrastinasi akademik memiliki hubungan yang kuat (signifikan) dengan prokrastinasi akademik pada mahasiswa di Kota Makassar.

\section{Pembahasan}

Besarnya korelasi antara konformitas dengan prokrastinasi akademik mahasiswa adalah 0,224. Besarnya kontribusi konformitas terhadap prokrastinasi akademik mahasiswa adalah sebesar 9,6\% sedangkan sisanya 90,4\% di tentukan oleh variabel lain. Adapun Variabel lain yang dapat mempengaruhi prokrastinasi akademik pada mahasiswa tersebut meliputi faktor internal dan faktor external. Sejalan dengan beberapa teori yang menjelaskan tentang faktor internal maupun faktor eksternal tersebut, Berk ${ }^{10}$ maupun Ghufron ${ }^{4}$ menggambarkan kedua faktor tersebut.

Prokrastinasi akademik pada mahasiswa bisa karena: (1) Faktor internal; Faktor internal adalah faktor-faktor yang terdapat dalam diri individu yang mempengaruhi prokrastinasi. Faktor-faktor itu meliputi: (a) kondisi fisik individu, faktor dalam diri individu yang turut memengaruhi munculnya prokrastinasi akademik adalah keadaan fisik dan kondisi kesehatan individu, misalnya fatigue. Seseorang yang mengalami fatigue akan memiliki kecenderungan yang lebih tinggi untuk melakukan prokrastinasi daripada yang tidak. Berbeda dengan tingkat inteligensi yang dimiliki seseorang, hal tersebut dianggap tidak memengaruhi perilaku prokrastinasi. Walaupun prokrastinasi sering disebabkan oleh adanya keyakinan-keyakinan yang irasional yang dimiliki seseorang. (b) kondisi psikologis individu. Menurut Millgram ${ }^{10}$, kepribadian individu mampu memengaruhi munculnya perilaku penundaan, misalnya kemampuan sosial yang tercermin dalam regulasi diri dan tingkat kecemasan dalam menjalin hubungan sosial. Besarnya motivasi yang dimiliki seseorang juga akan mempengaruhi prokrastinasi. Semakin tinggi motivasi intrinsik yang di miliki individu ketika menghadapi tugas, akan semakin rendah kecenderungannya untuk melakukan prokrastinasi akademik. (c). Kontrol diri.

Berbagai hasil penelitian juga menemukan aspek-aspek lain pada diri individu yang turut mempengaruhi seseorang untuk mempunyai suatu kecendurangan perilaku prokrastinasi antara lain rendahnya kontrol diri. Seseorang yang kurang mampu melakukan kotrol diri akan sering melakukan penundaan $^{3}$.(2). Faktor eksternal ${ }^{4}$, Faktor eksternal adalah faktor-faktor yang terdapat 
di luar diri individu yang mempengaruhi prokrastinasi. Faktor-faktor itu berupa pengasuhan orang tua dan lingkungan yang kondusif. (a) gaya pengasuhan orang tua, hasil penelitian Ferrari dan Ollivate $^{10}$ menemukan bahwa tingkat pengasuhan otoriter ayah menyebabkan munculnya kecenderungan perilaku prokrastinasi yang kronis pada subjek penelitian anak perempuan, sedangkan tingkat pengasuhan otoritatif ayah menghasilkan anak perempuan yang bukan prokrastinator. Ibu yang memiliki kecenderungan melakukan avoidance procrastination menghasilkan anak perempuan yang memiliki kecenderungan untuk melakukan avoidance procrastination pula. (b) kondisi lingkungan yang kurang terkontrol akan menyebabkan tingkat prokrastinasi yang cukup tinggi, sebaliknya kondisi lingkungan yang cukup terkontrol, disiplin namun hangat akan menyebabkan tingkat prokrastinasi yang rendah. Prokrastinasi akademik lebih banyak dilakukan pada kondisi pengawasan yang rendah daripada lingkungan yang penuh pengawasan. Namun, tingkat atau level sekolah, juga apakah terletak di desa ataupun di kota tidak mempengaruhi perilaku prokrastinasi seseorang.

\section{Kesimpulan dan Saran}

Berdasarkan hasil penelitian diketahui bahwa konformitas mempunyai hubungan yang sangat kuat dan signifikan dengan prokrastinasi akademik mahasiswa. Hal ini berarti bahwa hipotesisnya dalam penelitian ini diterima. Besarnya kontribusi konformitas dengan prokrastinasi akademik mahasiswa adalah sebesar 9,6 \% sedangkan sisanya $90,4 \%$ di tentukan oleh variabel lain yang mempengaruhi prokrastinasi akademik pada mahasiswa. Artinya jika konformitas dalam individu tersebut berdampak negatif maka akan mempengaruhi proses perkuliahan dan mengakibatkan prokrastinasi akademik atau penunda-nundaan akademik. Sebaliknya jika konformitas dalam individu berdampak positif maka akan lulus tepat waktu.

\section{Daftar Pustaka}

1. Undang-Undang R.I No. 20 Tahun 2003. Tentang Sistem Pendidikan Nasional.

2. Santrock, J.W. Adolescence: Perkembangan Remaja. Jakarta : Erlangga. 2003

3. Susanti, Elly, Nurwidayanti dan Desi. Hubungan antara Kontrol Diri dan Konformitas dengan Prokrastinasi Akademik pada Mahsiswa Program Psikologi Unesa. Jurnal Character. 2014; Vol. 2 No.3.

4. Andarini Sekar Ratna, Anne Fatma. Hubungan Antara Distress Dan Dukungan Sosial Dengan Prokrastinasi Akademik Pada Mahasiswa Dalam 
Menyusun Skripsi. Jurnal Talenta Psikologi. 2013;Vol.2 No. II.

5. Aryatmi, S. Membina Pribadi Mahasiswa Melalui Perguruan Tinggi dalam Kepribadian Siapakah Saya?. Jakarta: Rajawali. 1992.

6. Taylor, Shelley E. Psikologi Sosial. Eds.kedua belas. Jakarta: Kencana. 2009

7. Azwar, Saifuddin. Metode Penelitian. Yogyakarta: Pustaka Pelajar. 2013

8. Azwar, Saifuddin. Realibitas dan Validitas. Yogyakarta: Pustaka Pelajar. 2001

9. Azwar, Saifuddin. Penyusunan Skala Psikologi. Eds. Kedua. Yogyakarta: Pustaka Pelajar. 2013

10. Berk, Laura E. Development Throught The Lifespan (Dari Masa Dewasa Awal Sampai Menjelang Ajal). Yoyakarta: Pustaka Pelajar. 2010Y

11. Ghozali, Imam. Aplikasi Analisis Multivariate dengan Program SPSS. Semarang: Badan Penerbit UNDIP. Semarang. 2005 


\section{Tabel 1}

Rangkuman Hasil Uji Normalitas

\begin{tabular}{lllll} 
Variabel & K-SZ & Sig & Syarat & Keterangan \\
Konfornitas & 0,184 & 0,000 & P $>0,05$ & Normal \\
Prokrastinasi Akademik & 0,174 & 0,000 & P $>0,05$ & Normal \\
\hline
\end{tabular}

\section{Tabel 2}

Rangkuman Hasil Uji Linearitas

\begin{tabular}{lll}
\hline Korelasi X dan Y & Signifikansi & Status \\
\hline Linearity & 0,002 & \\
Deviation From Linearity & 9,633 & Linear \\
\hline
\end{tabular}

\section{Table 3}

Hasil Analisis Product Moment

\begin{tabular}{lll}
\hline Variabel X dan Y & $\mathbf{P}$ & Kesimpulan \\
\hline 0,224 & 0,002 & Hubungan sangat signifikan \\
\hline
\end{tabular}

